\title{
HEALTHY MOUTH - HEALTHY YOU : A MINI REVIEW
}

\author{
Sonia Joshi ${ }^{1}$, Deepti Garg Jindal ${ }^{2}$, Bhavna Rani ${ }^{3}$, Namita Sepolia ${ }^{4}$ \\ ${ }^{1}$ Senior Lecturer, Department of Oral Pathology and Microbiology, Bhojia Dental College and Hospital, Himachal Pradesh \\ ${ }^{2}$ Reader, Department of Oral Pathology and Microbiology, Bhojia Dental College and Hospital, Himachal Pradesh \\ ${ }^{3}$ PG Student, Department of Oral Pathology and Microbiology, Bhojia Dental College and Hospital, Himachal Pradesh \\ ${ }^{4}$ PG Student, Department of Oral Pathology and Microbiology, Bhojia Dental College and Hospital, Himachal Pradesh
}

\section{ABSTRACT}

Oral diseases are among the most common diseases of human kind, yet they receive little attention in many countries with weak health care systems. Despite a high social and economic burden from oral diseases they are considered a neglected area of international health. The purpose of this mini review is to highlight the effects of oral health on general body and vice versa as well as strategies for improving oral health.

Keywords: Diseases, Health, Oral

\section{INTRODUCTION}

Oral health is more than dental health. It includes healthy gums, hard and soft palate, linings of the mouth and throat, tongue, lips, salivary glands, chewing muscles, and upper and lower jaws. The oral cavity plays a central role for intake of basic nutrition and protection against microbial infections.

The World Health Organization (WHO) defines oral health as "a state of being free from mouth and facial pain, oral and throat cancer, oral infection and sores, periodontal (gum) disease, tooth decay, tooth loss, and other diseases and disorders that limit an individual's capacity in biting, chewing, smiling, speaking, and psychosocial wellbeing". Oral health is a human right, an integral part of general health and essential for overall well being . ${ }^{2}$

\section{CONNECTION BETWEEN ORAL} HEALTHAND GENERAL HEALTH

Oral health and general health have

to infection, inflammation, and other serious impacts on overall health. Thus, maintaining good oral health is crucial to sustain general health and vice versa (Figure 2). ${ }^{4}$

\section{STRATEGIES FOR IMPROVING} ORAL HEALTH (Table: 1).

Oral health can be improved with a number of strategies and efforts based on collaborative and intersectoral approaches. ${ }^{5,6,7}$

\section{CONCLUSION}

Oral health is integral to general health and a basic human right. Concerted and collaborative action needs to be mobilized, maintained and strengthened to address the high burden of oral disease and the vast inequities in access to oral health care existing within and between countries. The integration of oral health into general health approaches, is a realistic opportunity to raise the profile of oral health and to end the international neglect of oral diseases.
\end{abstract}

Corresponding Author: Sonia Joshi

E-mail:

soniajoshiop@gmail.com

Received: $15^{\text {th }}$ January 2017

Accepted: $23^{\text {rd }}$ April 2017

Online: $20^{\text {th }}$ May 2017 close linkages. On the one hand, oral health can be compromised by a number of chronic and infectious diseases which show symptoms in the mouth (Figure 1). ${ }^{3}$ On the other hand, oral diseases can lead

\section{REFERENCES}

1. World Health Organization. The Liverpool Declaration: Promoting Oral Health in the 21 st Century. A call for action. September 2005. Available at: www.who.int/oral_health/ 


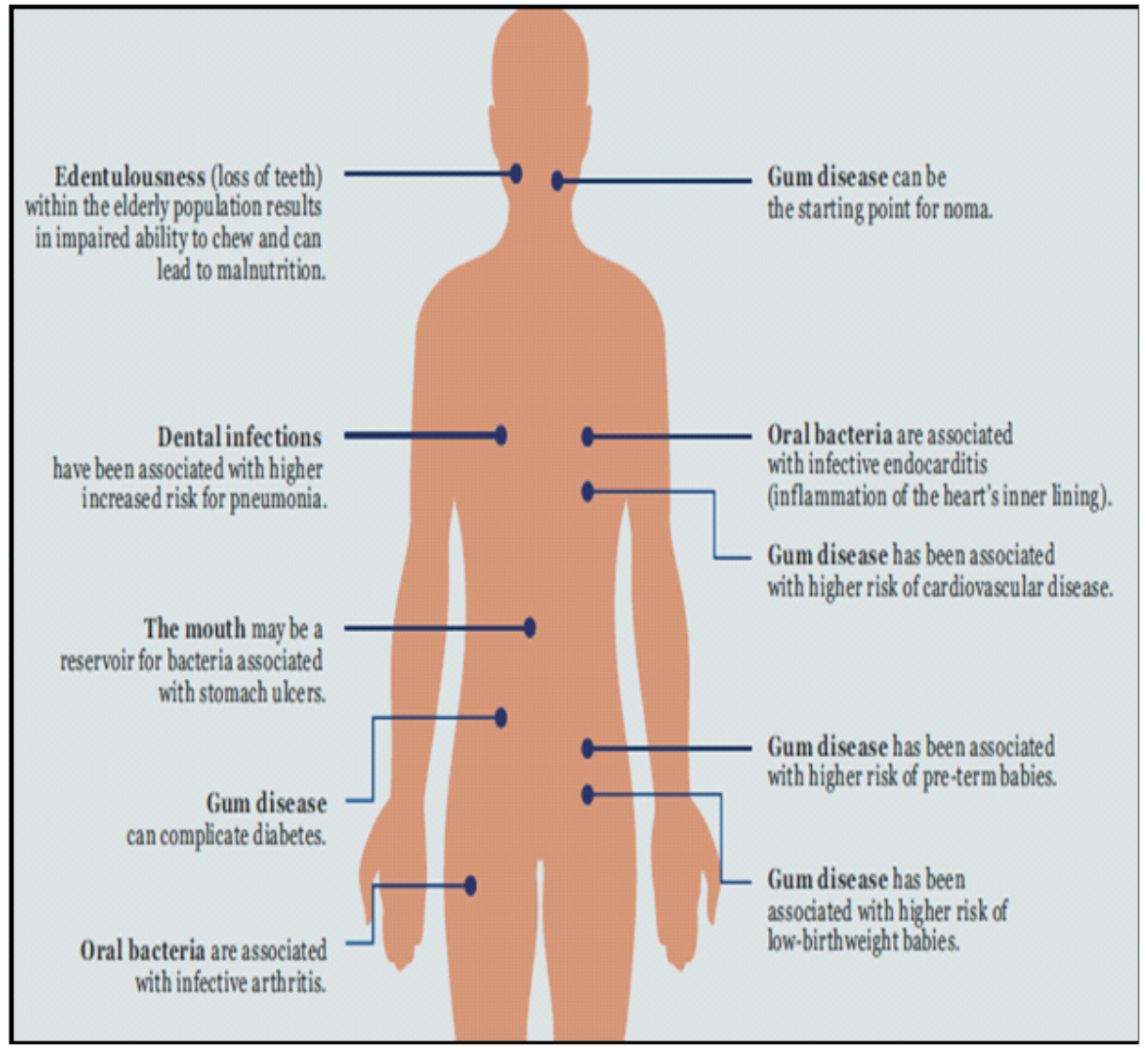

Figure 1: Impacts of oral conditions on general health

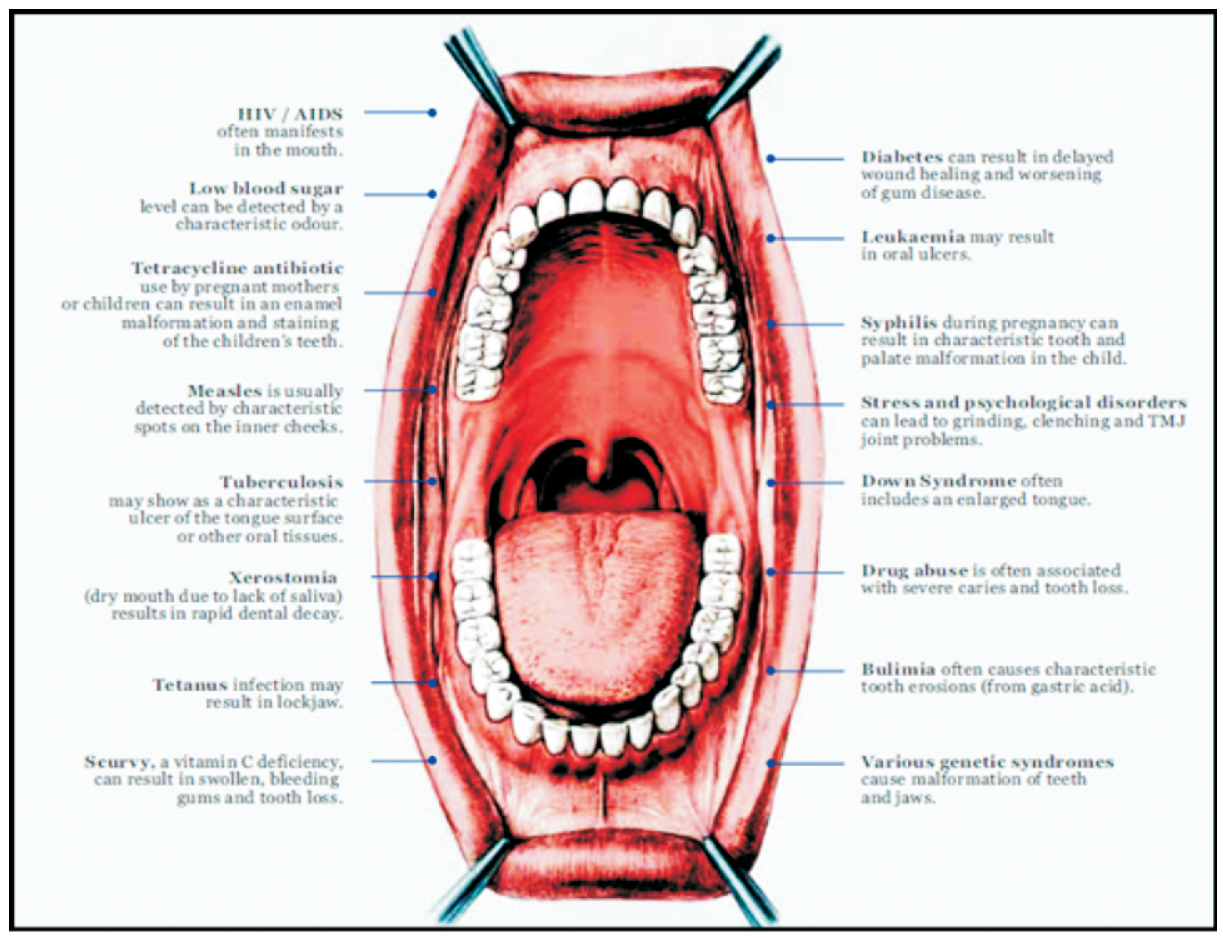

Figure 2: Impacts of systemic disease on oral health 


\begin{tabular}{|l|l|}
\hline $\begin{array}{l}\text { Prevention of oral disease } \\
\text { and promotion of oral } \\
\text { health }\end{array}$ & $\begin{array}{l}\text { Prevention of oral diseases and promotion of oral health must be at the core } \\
\text { of national policies and programmes. This includes reducing risk factors of } \\
\text { oral diseases and their associated determinants as well as strengthening } \\
\text { awareness of healthy behaviors and health literacy. }\end{array}$ \\
\hline $\begin{array}{l}\text { Universal access to } \\
\text { affordable and effective } \\
\text { fluoride }\end{array}$ & $\begin{array}{l}\text { Exposure to fluoride is the single most cost-effective measure to prevent } \\
\text { tooth decay and improve oral health. Regular use of fluoride toothpaste is } \\
\text { the most important way to ensure a good preventive effect. }\end{array}$ \\
\hline $\begin{array}{l}\text { Human resources for oral } \\
\text { health and public oral } \\
\text { health }\end{array}$ & $\begin{array}{l}\text { The training of the oral health workforce needs to be strengthened, expanded } \\
\text { to improve the quality and increase the number of oral health professionals. }\end{array}$ \\
\hline $\begin{array}{l}\text { Integration of oral health } \\
\text { care into Primary Health } \\
\text { Care }\end{array}$ & $\begin{array}{l}\text { To achieve equity in oral health care, essential oral health care measures } \\
\text { need to be integrated in Primary Health Care including relief of pain, } \\
\text { promotion of oral health and management of oral diseases and conditions. }\end{array}$ \\
\hline $\begin{array}{l}\text { Oral health Information- } \\
\text { Surveillance, Monitoring } \\
\text { and Evaluation }\end{array}$ & $\begin{array}{l}\text { Global and national surveillance should be strengthened to identify risk } \\
\text { factors and oral health needs as a basis for developing appropriate } \\
\text { approaches and measures. Monitoring and evaluation are critical for } \\
\text { ensuring the effectiveness and sustainability of interventions. }\end{array}$ \\
\hline $\begin{array}{l}\text { Funding and policies } \\
\text { based on oral health } \\
\text { priorities }\end{array}$ & $\begin{array}{l}\text { Oral health policies and action plans need to be developed and maintained } \\
\text { nationally and locally reflecting the particular oral health needs. Basic and } \\
\text { essential emergency care should be included in benefit packages of social } \\
\text { health insurances to guarantee universal access for all. }\end{array}$ \\
\hline School oral health & $\begin{array}{l}\text { Schools and pre-schools are ideal settings to promote oral health. Supportive } \\
\text { school policies, the physical environment and skills-based health education } \\
\text { are essential in maintaining oral health and the control of risk behaviours. }\end{array}$ \\
\hline
\end{tabular}

Table 1: Strategies for Improving Oral Health

events/orh_liverpool_declaration_05.pdf.

2. Tomar SL, Asma S. Smoking-attributable periodontitis in the United States: findings from NHANES III. National Health and Nutrition Examination Survey. J Periodontol 2000;71:743-51.

3. Marcenes W, Kassebaum NJ, Bernabe E, Flaxman A, Naghavi M, Lopez A, Murray CJ. Global Burden of Oral Conditions in 1990-2010: A Systematic Analysis. J Dent Res 2013;92:5927.

4. Benzian H, Hobdell M, Holmgren C, Yee R, Monse B, Barnard JT, van Palenstein Helderman W. Political priority of global oral health: an analysis of reasons for international neglect. Int Dent J 2011; 61:124-30

5. FDI, WHO, ADEA, ADA, WHO PAHO, IFDEA, IADR,AADR, AAPD. Oral Health - Integration and Collaboration. Testimony for the 2005 Global Health Summit, Philadelphia,Pennsylvania, June 5, 2005.

6. Petersen PE, Ogawa H. The global burden of periodontal disease: towards integration with chronic disease prevention and control. Periodontol 2000 2012;60:15-39.

7. Glick M, Monteiro da Silva O, Seeberger GK et al. FDI Vision 2020: shaping the future of oral health. Int Dent J 2012 62: 278-91. 